\title{
Gender asymmetry peculiarities among lecturers of foreign languages department
}

\author{
Galina Viktorovna Tretyakova ${ }^{*}$, and Farrukh Begijon Khudoydodzoda ${ }^{2}$ \\ ${ }^{1}$ Financial University under the Government of the Russian Federation, Department of Foreign \\ Languages and Intercultural Communication, Moscow, Russia \\ ${ }^{2}$ Tajik National University, Department of Ontology and Theory of Cognition, Dushanbe, Tajikistan
}

\begin{abstract}
The background of the research: the article deals with the problems of gender asymmetry among teachers of the Department of Foreign Languages and Intercultural Communication of the Faculty of International Economic Relations, which are caused by the socio-economic structure of society, the level of democratization, the development of the spiritual life of society, the peculiarities of the socio-demographic structure. It is also necessary to take into account the experience of the Soviet school, which had a pronounced gender asymmetry, which had led to the feminization of many professions. The gender factor is important when planning the work of universities, determining the areas of training and specialties that are in demand by the market. Under such conditions, gender asymmetry becomes a clear indicator of the educational society. So, the purpose of the study is to conduct a gender analysis of the ongoing changes in the higher education system and to show the professional and social role of women in the modern world.
\end{abstract}

Keywords: principles of historicism, gender factor, society of teachers, gender strategy

\section{Introduction}

The concept of "gender" was introduced into scientific circulation in the fifties by American scientists. Now it denotes any mental or behavioral properties that supposedly distinguish men from women and thus is associated with masculinity and femininity. In pedagogy, gender means the socially determined role, identity, and sphere of activity of men and women, depending not on biological sex differences, but on the characteristics of the social organization of a particular society [1]. Gender asymmetry is a phenomenon that reflects the objective regularity of the quantitative distribution of men and women in the social structure of a society and in all the spheres of its life in favor of the male or female community.

\footnotetext{
* Corresponding author: gvtretvakova@fa.ru
} 


\section{$2 \quad$ Materials and methods}

This article develops a set of socio-methodological support for the study of gender asymmetry in the professional society of foreign language teachers, explains the nature of stereotypes, shows their historical variability and social conditionality. Society cannot be fully democratic without the full-scale inclusion of women in the process of education, the development of scientific and methodological thought. Today, Russia is trying to enter the European community and take its rightful place there. Eliminating all the forms of discrimination, including gender-based discrimination, will help it do this. The transition to the information society today - a society of intelligence, knowledge and thinking-creates basic opportunities for self-development and self-realization for each person. The need to adopt a gender strategy is determined by the social problems caused by socio-economic and political transformations. In this regard, an interdisciplinary approach, system analysis, the principles of historicism and continuity, and social determinism were used.

\section{Results}

Since the $60-70$ s of the twentieth century, the problem of social inequality between men and women or gender asymmetry in various spheres of human activity, including the sphere of labor and employment, which is inextricably linked with the field of vocational training and education, has taken a central place in gender studies. A huge number of scientific works are devoted to this problem, but it remains relevant in the light of global socio-economic and cultural transformations and the formation of a new strategy aimed at preserving human capital and sustainable development of a society [2]. Among modern researchers, the prevailing opinion is that it is in the sphere of labor and employment that gender asymmetry is most pronounced: for various reasons, women tend to work in less prestigious sectors of the economy, are more often discriminated against at work, and less often occupy high-paid positions and positions associated with making politically significant decisions [3]. Some scientists criticize these provisions, citing the example of the education system, which, in their opinion, has already achieved an equal ratio of men and women in the structure of administrative and teaching staff, including the provisions in terms of salary and career opportunities [4]. Nevertheless, there is no doubt that there is a real problem of professional differentiation based on gender and imbalance in the field of employment in a society. It manifests itself not only in the different levels of the positions prestige which are held by men and women, the amount of their wages, but also in the existence of stereotypical ideas that affect the choice of future specialty and professional orientation within the educational system. Let us turn to the statistics. According to the data of sociological studies conducted in 2015-2019, the level of professions prestige for men was distributed as follows in a descending order: a lawyer, an economist, a programmer, a physician, an engineer, a merchant, a translator, a researcher, etc.; the professions of a psychologist and a teacher have taken the last places in the rating. The professional selection of women was as follows (also in a descending order): an economist, a lawyer, a physician, a translator, a teacher, some creative professions, an engineer, a psychologist, a merchant, etc.; the last place was taken by the profession of a programmer [5].

Modern realities and the total informatization of a society have set new priorities and brought new specialties to the fore. Numerous resources dedicated to the career guidance and the search for future work, orient men to the professions of an IT specialist, banking 
specialties, the professions of an architect, an engineer, a doctor, a sales specialist, a marketer, an accountant [6]. For women, the list of recommended professions in the first place is as follows: a doctor, a PR specialist, a psychologist and a personal consultant, a marketer, an ecologist, a chemist, a service specialist, an IT specialist (but not in the first positions), an engineer, etc. [7]. Despite some blurring of the boundaries, there are still very significant gender differences in professional orientation and the choice of a future field of work, confirmed, among other things, by professional sociological studies [8]. There is still a clear understanding of the "traditional" male and female professions, as well as the predominance of divergent interests among men (technical and scientific) and women (mainly humanities)[9].

Such an asymmetry can be seen in the composition of teachers of any professional educational institution, and in this regard, the Department of Foreign Languages and Intercultural Communication of the Faculty of International Economic Relations is no exception.

Table 1. Personnel of the Department of Foreign Languages and Intercultural Communication of the Financial University under the Government of the Russian Federation.

\begin{tabular}{|l|c|c|}
\hline \multicolumn{1}{|c|}{ Personnel structure } & Women & Men \\
\hline Total & $74 \%$ & $26 \%$ \\
\hline Top managers & $98 \%$ & $2 \%$ \\
\hline Candidates of Science & $48 \%$ & $4 \%$ \\
\hline Associate Professors & $39 \%$ & $2 \%$ \\
\hline Professor & $1 \%$ & $1 \%$ \\
\hline
\end{tabular}

The personnel composition of our Department (Table 1) is represented by the overwhelming majority of the female contingent (74\%), including candidates of Science- $48 \%$, men-26\%, top managers- $98 \%$ and $2 \%$, respectively, candidates of Science- $48 \%$ are women, and $4 \%$ are men. The asymmetry is obvious, but in favor of women. At the same time, women perfectly cope with their administrative tasks. The Department of Foreign Languages and Intercultural International Communication of the Financial University under the Government of the Russian Federation occupies a leading position in many indicators: in educational activities, science, extracurricular activities. We have a parity in the number of professors. In terms of wages, there is also a full parity.

Is such a distribution considered to be appropriate and even natural, even if it includes many mutually influencing factors for determining professional orientation? Or does it reflect the dependence of a society on established stereotypes that can negatively affect the further development of the field of professional activity? On the one hand, there is no doubt that there are psychophysiological features that manifest themselves in men and women from the first days of their birth [10], and in the future they are displayed in a deeper and brighter way [11]. On the other hand, it is also indisputable that the excessive emphasis on gender differences and the uncompromising opposition of the male and female principles give rise to discrimination, the lack of equal cooperation between the sexes [12]. The gender differences and characteristics dictated by a society become less unambiguous when it comes to the individual characteristics of the development of a particular person, his or her inclinations, life and professional priorities. A person needs to see his or her development prospects and his or her role and place in the social processes that affect his or her future life. Therefore, the process of social adaptation without taking into account the gender factor of self-actualization creates real problems of socialization and career 
guidance of the individual, an unacceptable narrowing of the boundaries of thinking in a rapidly changing world [13].

Of course, our main mission is to provide educational services in the field of teaching foreign languages. Among the students of the Department of Foreign Languages and Intercultural Communication, a survey of students concerning the professional skills of teachers was conducted according to the following criteria (Table 2):

Table 2. Study of students' opinions on the professional skills of teachers of the Department of Foreign Languages and Intercultural Communication.

\begin{tabular}{|l|c|c|}
\hline \multicolumn{1}{|c|}{ Evaluation criteria } & Women & Men \\
\hline AVERAGE (5-point scale) & 4.59 & 4.42 \\
\hline $\begin{array}{l}\text { Is able to clearly, easily } \\
\text { and consistently present the } \\
\text { material }\end{array}$ & 4.57 & 4.48 \\
\hline $\begin{array}{l}\text { Connects the theoretical } \\
\text { knowledge with the } \\
\text { practical component of the } \\
\text { future profession }\end{array}$ & 4.67 & 4.64 \\
\hline $\begin{array}{l}\text { Is able to motivate and } \\
\text { engage the student in the } \\
\text { learning process }\end{array}$ & 4.81 & \\
\hline $\begin{array}{l}\text { From the first lesson in the } \\
\text { discipline puts forward } \\
\text { clear and understandable } \\
\text { requirements for the } \\
\text { knowledge assessment at } \\
\text { classes, certifications and } \\
\text { exams }\end{array}$ & 4.84 & \\
\hline $\begin{array}{l}\text { Objective in assessing } \\
\text { students' knowledge and } \\
\text { their completed work }\end{array}$ & 4.81 & 4.76 \\
\hline $\begin{array}{l}\text { Interested in improving the } \\
\text { level of students } \\
\text { knowledge acquiring and } \\
\text { their skills in the taught } \\
\text { discipline }\end{array}$ & 4.92 & \\
\hline $\begin{array}{l}\text { Always friendly and tactful } \\
\text { with students }\end{array}$ & & \\
\hline $\begin{array}{l}\text { Available for the } \\
\text { extracurricular } \\
\text { communication on } \\
\text { educational and scientific } \\
\text { issues at consultations or } \\
\text { remotely }\end{array}$ & 4.71 & 4.68 \\
\hline
\end{tabular}

\section{Discussion}

As a result, it was found that the indicators of male teachers are inferior to the average indicators of female teachers by $0.5 \%$. In addition, during an oral survey of 365 students of the Faculty of International Economic Relations it turned out that $98 \%$ of students still do not see the difference between male and female teachers. For them, the priority was such 
qualities as professionalism, love for the profession, the ability to establish contact with the audience.

Thus, we can conclude that the true equality of rights and freedoms can be achieved only on the basis of recognizing the value of each individual, creating stable conditions for the self-development of the human intelligence, the fullest realization of its creative potential and creative abilities, the full disclosure of essential forces and talents, which will ensure the full contribution of everyone to the development of a society[15]. The transition of many countries to an information society - a society of intelligence, knowledge and thinking-creates basic opportunities for self-development and self-realization for each person. The need to adopt a gender strategy is determined by the social problems caused by socio-economic and political transformations. Along with the opening of new perspectives for the wide application of human abilities, high adaptive capabilities are required from people [14].

\section{Conclusion}

In order to create favorable conditions for the growth of opportunities for self-realization of the individual, the modern society should take care of rethinking the traditional cultural limitations of the potential of the individual development depending on gender and pay attention to the problem of gender asymmetry, which persists, including in the field of higher education. Gender issues contribute to a deeper understanding of human rights, a modern understanding of the concepts of sustainable democratic development. Mastering the basics of gender knowledge helps to free yourself from the "captivity" of gender stereotypes. Gender education contributes to the growth of self-awareness, active integration into all spheres of a society. As for the Department of Foreign Languages and Intercultural International Communication of the Faculty of International Economic Relations, the pronounced asymmetry of the personnel structure in no way affected the implementation of our main mission - the effective foreign language teaching the future international specialists.

\section{References}

1. F.D. Blau, J Econ Lit, 36, 112-165 (2018)

2. F.D. Blau, P. Brummund, A.Y. Liu, Demography, 50, 471-492 (2013). https://doi.org/doi:10.1007/s13524-012-0151-7

3. M. Bertrand, E. Kamenica, J. Pan, The Quart J Econ, 130, 571-614 (2015). https://doi.org/10.1093/qje/qjv001

4. M.Bittman, et al., Amer J Soc, 109, 186-214 (2013). https://doi.org/10.1086/378341

5. H. Blossfeld, Annual Rev Soc, 35, 513-530 (2019). https://doi.org/10.1146/annurev-soc-070308-115913

6. H.A. Schwartz, et al., PLoS One, 8(9), e73791 (2018). https://doi.org/10.1371/journal.pone.0073791

7. K. Schwab, et al., The Global Gender Gap Report 2018 (World Economic Forum, 2018)

8. M. Hout, Mobility tables (SAGE, Beverly Hills, 2013) 
9. N.L. Graf, C.R. Schwartz, Gender Soc, 25, 101-107 (2011).

https://doi.org/10.1177/0891243210390356

10. C. Goldin, M. Shim, J Econ Persp, 18, 143-160 (2014).

https://doi.org/10.1257/0895330041371268

11. F.D. Blau, L.M. Kahn, The Acad Manag Persp, 21, 7-23 (2017).

https://doi.org/10.5465/AMP.2007.24286161

12. K.A. Ratliff, S. Oishi, J Person Soc Psy, 105, 688-702 (2013).

https://doi.org/10.1037/a0033769

13. T. Greenstein, Annual Rev Soc, 35, 87-105 (2019).

https://doi.org/10.1146/annurev-soc-070308-115920

14. S.S. Iyengar, E. Kamenica, I. Simonson, Quart J Econ, 121, 673-697 (2006).

https://doi.org/10.1162/qjec.2006.121.2.673

15. F. Hou, J. Myles, Canad J Soc, 33, 337-366 (2018) The status of women in the States: 2015. Accessed on: September 24, 2021. [Online]. Available:

https://iwpr.org/iwpr-publications/report/the-status-of-women-in-the-states-2015/ 